\title{
À SOMBRA DE UM DIÁLOGO: HEIDEGGER E A POÉTICA DE AUGUSTO DOS ANJOS
}

\author{
In the shadow of a dialogue: Heidegger and the poetry of Augusto dos Anjos
}

A la sombra de um diálogo: Heidegger y la poética de Augusto dos Anjos

FranCisCo B. S. FiLHO

SYMONE F. MELO

\begin{abstract}
Resumo: Na composição deste artigo busca-se promover um encontro entre o pensamento filosófico de Heidegger e a poética de Augusto dos Anjos. O pensamento de Heidegger, num momento denominado reviravolta, se afasta das terminologias fenomenologia e hermenêutica. A proposição do filósofo, doravante, passa a se voltar para a linguagem e a se denominar topologia do ser. Portanto, a obra de arte, com especial relevo na poesia, é manancial de onde brotam a desocultação e a revelação de mundo e terra, nos termos heideggerianos. Com arrimo nesse entendimento, fez importante um estudo em torno das contribuições de Heidegger à fenomenologia existencial, com relevo ao segundo momento de sua produção ou caminho. A partir de então, se afigurou necessário que se tangenciasse a singularidade de Augusto dos Anjos, expressa em sua história e sua poética, em diálogo com o pensamento filosófico heideggeriano. Augusto dos Anjos resgata o mundo em estado puro e a linguagem como possibilidade de sentido. Em direção convergente, Heidegger caminha rumo ao desvelamento do Ser, que se dá diante da angústia colada à existência e da possibilidade extrema do não-ser, em face de sua condição de ser-para-a-morte. O diálogo entre o filósofo e o poeta revelou-se instigante e profícuo. Palavras-chave: Fenomenologia, Existencialismo, Linguagem, Heidegger, Augusto dos Anjos.
\end{abstract}

\begin{abstract}
This article seeks to promote a meeting between Heidegger's philosophical thinking and the poetics of Augusto dos Anjos. Heidegger's thinking, at a time called turning, departs from the terminology of phenomenology and hermeneutics. The proposition of the philosopher, henceforth, begins to turn to language and to be called the topology of being. Therefore, the work of art, with special emphasis on poetry, is the source from which the unveiling and the revelation of world and earth, in the Heideggerian terms, spring forth. Based on this understanding, a study was made of Heidegger's contributions to existential phenomenology, with emphasis on the second moment of his production or path. From then on, it appeared necessary to tangentiate the singularity of Augustus of the Angels, expressed in his history and his poetics, in dialogue with Heidegger's philosophical thought. Augustus of the Angels rescues the world in its pure state and language as a possibility of meaning. In a convergent direction, Heidegger walks toward the unveiling of the Being, which occurs in the face of the anguish of existence and the extreme possibility of non-being, in the face of its being-to-death condition. The dialogue between the philosopher and the poet was thought provoking and fruitful. Keywords: Phenomenology, Existentialism, Language, Heidegger, Augusto dos Anjos.
\end{abstract}

Resumen: En la composición de este artículo, buscamos promover una reunión entre el pensamiento filosófico de Heidegger y la poesía de Augusto dos Anjos. El pensamiento de Heidegger, en un momento llamado "cambio de tendencia”, se aparta de la fenomenología y de la hermenéutica. La proposición del filósofo, a partir de ahora, es volver a la lenguaje y a la denominación "topología del ser". Por lo tanto, la obra de arte, con especial énfasis en la poesía, es la fuente de la que brotan desenmascaramiento y la revelación del mundo y de la tierra, en términos de Heidegger. Con retenimiento en esta comprensión, se hizo importante un estudio en torno a las aportaciones de la fenomenología existencial de Heidegger, con énfasis en la segunda etapa de su producción o camino. Desde entonces, se ha comprobado que es necesario tangenciar la singularidad de Augusto dos Anjos, expresa en su historia y en su poética, en diálogo con el pensamiento filosófico de Heidegger. Augusto dos Anjos rescata el mundo en estado puro y el lenguaje como posibilidad de sentido. En dirección convergente, Heidegger camina hacia el desvelamiento del Ser, que se da ante la angustia pegada a la existencia y la posibilidad extrema del no ser, frente a su condición de ser para la muerte. El diálogo entre el filósofo y el poeta se mostró instigador y provechoso.

Palabras-claves: Fenomenología, Existencialismo, lenguaje, Heidegger, Augusto dos Anjos. 
Sou uma sombra, venho de outras Eras! Do cosmopolitismo das moneras... Pólipo de recônditas reentrâncias,

Larva de caos telúrico, procedo

Da escuridão do cósmico segredo,

Da substância de todas as substâncias.

(Anjos, 1998, p.49)

Já o verme - este operário das ruínas -

Que o Sangue podre das carnificinas

Come, e à vida em geral declara guerra,

Anda a espreitar meus olhos para roê-los,

E há de deixar-me apenas os cabelos,

$\mathrm{Na}$ frialdade inorgânica da terra!

(Anjos, 1998, p.56)

Aprender a existir no inefável é o aprendizado para que o homem retome a proximidade do ser (Heidegger, 2005). E o inefável reside na Arte, expressão originária do ser, e na linguagem, especialmente a linguagem poética, como restabelecimento do sagrado e da verdade de um ser, que fora esquecido e manietado nos porões da técnica, da estética e da metafísica. O preâmbulo sintetiza o intento deste estudo, que objetiva o estabelecimento de um diálogo entre a poética de Augusto dos Anjos e o pensamento de Martin Heidegger, sobremaneira ao momento de sua trajetória intitulado viragem ou segundo Heidegger. Debruçaremos-nos sobre esses escritos, desnudos da preocupação meramente teórica e o faremos, tendo em mira a perspectiva sugerida na obra A caminho da linguagem (de sua lavra), num diálogo do pensador com poemas da obra Eu e Outras Poesias, de Augusto dos Anjos. Poeta brasileiro, paraibano que resgata o assombro e a sacralidade da existência em poemas, como os acima destacados, pontilhados de vida e balizadores, para o ser se recolher à clareira de sua existência. Recolhimento "que o sujeita ao risco do estranho, e que descerra o âmbito do desvelamento, tal como a maré vazante descerra a praia, a palavra poética dimensiona o mundo e o próprio homem” (Nunes, 1992, p.268).

\section{Martin Heidegger: pelas trilhas do poético.}

A perspectiva hermenêutica heideggeriana notabiliza-se, em distinção à fenomenologia transcendental de Husserl, por perceber a redução como uma abertura originária de sentido ao ser, não mais numa disposição transcendental, mas em processo de co-originalidade com o mundo, no qual são consideradas entonações afetivas próprias da existência, tais como: a angústia, o tédio, e a serenidade (Souza, Leal \& Sá, 2010). Nesse contexto, “cumpre substituir o sujeito transcendental - que terá decididamente conhecido muitas vicissitudes - pela existência em sua facticidade, o que Heidegger chama de Dasein” (Dartigues, 2005, p.113). E à fenomenologia hermenêutica cabe desvendar o sentido do texto da existência, que comporta os elementos de sua própria compreensão, camuflado no que se revela como realidade dada e inexorável ou no falatório e escritório - que podem ser expressos como modos de ser cotidianos, inautênticos e tendentes ao fechamento do Dasein, em grande parte dos casos.

A condição de ser-no-mundo, sugere abertura e relação posto que, distinto dos entes (que não constituem abertura de sentido) o homem caminha sempre em contexto relacional, mesmo diante do isolamento. Esse modo-de-ser-em-relação, do Dasein, se dá numa perspectiva de ocupação com os entes, cujo modo de ser é dado e de preocupação, em se tratando com os que lhes são pares em termos de modo de ser. Evidencia-se, nesse caso, a característica ontológica do Dasein de sempre referenciar outro ente. Quando o sentido relacional é tomado como simplesmente dado e essa "funcionalidade" não se revela como fundamento seguro, abrem-se, então, possibilidades para outros sentidos e, em forma de angústia, surge “então o 'estranhamento', que faz com que os entes não mais apareçam como simplesmente dados e, consequentemente, a responsabilidade, até então 'esquecida', de assumir a liberdade de poder-ser de diferentes maneiras” (Sá, 2013, p.370). Logo, advém a angústia se apresentando como disposição afetiva, que rompe com a cotidianidade, revelando o poder-ser mais genuíno ao Dasein, abertura de possibilidades para um ser fadado à inconclusão.

Dentre as possibilidades do Dasein, a morte é possibilidade extrema (posto que também é sua impossibilidade) e antecedente ao seu poder-ser, porque morrendo ele deixa de ser no mundo e, portanto, fenecem-lhe todas outras possibilidades. Assim, sendo ser-para-morte, condição que abarca o Dasein desde o nascimento, infere-se que toda angústia sugere angústia da morte (Sá, 2013) e angústia diante do nada, que revela e ilumina o ser-no-mundo, circunstância antes obscurecida por uma existência inautêntica. (Dartigues, 2005). Em torno do fenômeno da morte, há uma tendência a seu encobrimento ou a contorná-lo, não obstante esse movimento dificultar a percepção do ser-para-morte como modo próprio de ser no mundo, em que a existência está constantemente em revisão e não mergulhada na impessoalidade acrítica. Nessa condição, concorre uma convocação a um modo de ser mais próprio, que Heidegger vai identificar como clamor, momento em que o Dasein se volta às suas possibilidades mais peculiares (como Ser), optando pelo projeto de existência mais singular e revelador de si mesmo.

O pensamento de Heidegger, num momento denominado reviravolta, se afasta das terminologias fenomenologia e hermenêutica. Faz-se mister entender que, com a filosofia de Hegel (que advogou o domínio da realidade, dissecada pela razão histórica) e sua releitura por Marx percebendo a superação da Filosofia pela necessidade de sua realização, insti- 
tui-se o fim da Filosofia. Marco desse período é o início da civilização mundial fulcrada no pensamento ocidental europeu (pensamento calculante). Noutros termos, "o fenômeno do acabamento da filosofia na era da ciência marcará a interpretação científica do mundo, isto é, as ciências interpretarão o que outrora fora interpretado pela filosofia em um sentido ontológico" (Silva, 2012, p.155). É a hegemonia mundial da técnica, que subsume o papel da Filosofia na realização das ciências empíricas. Uma realidade que "ensombrece a clareira em que o Dasein se encontra, sempre a derradeira primavera da Filosofia [mas que] pode anunciar o verão de um novo modo de pensar, de um novo começo do pensamento, na expectativa do qual se empenha a prática meditante de Heidegger" (Nunes, 1992, p. 247).

A proposição heideggeriana, doravante, passa a se voltar para a linguagem e a se denominar topologia do ser. Ser, cuja finitude foi desvelada e o sentido fundamental deslocado do espetáculo do mundo e das ideias, revelando-se por uma existência que foge à dominação da técnica, da ciência e da metafísica. Nesse diapasão, o ser não constitui o conteúdo do pensamento (embora, pensar o ser seja sua vocação), mas ambiência para o pensamento; fato que não estimula sua concepção ou entendimento sob o primado de um cânone técnico. Linguagem, uma linguagem reveladora do ser, pensamento do ser, tão somente linguagem; não aquela científica, aplicada, constituída pelo homem a partir de representações subjetivas e de sua ilusão de ter-lhe criado um sentido e precisa representação. Para Heidegger (2003), uma linguagem genuína, plena e inaugural, só encontrada no poema. Inaugural, posto que a linguagem é começo e fim, espaço do ser "em que se abastecem os poetas e os pensadores, e em torno do qual eles convergem no caminho de retorno ao país natal, à residência poética do homem” (Nunes, 1992, p. 278).

Nesse sentido, a "linguagem é a casa do ser. Nesta habitação do ser mora o homem. Os pensadores e os poetas são os guardas desta habitação. A guarda que exercem é o ato de consumar a manifestação do ser, na medida em que a levam à linguagem e nela a conservam" (Heidegger, 2005, p.8). Morar na linguagem sinaliza, a partir da poesia (vista por Heidegger como intrínseca a toda manifestação de arte, sobretudo àquela contida no poema), o desvelamento do Ser e o encontro com a verdade. Não aquela verdade propugnada pela estética, que concebe a arte como objeto da prática de uma subjetividade ou coisa, atribuindo-lhe objetivamente uma descrição; mas como aletheia: "a verdade do ser, a clareira (die Lichtung) que possibilita clarificar (des-velar) a originariedade instauradora do comum-pertencer de ser e homem" (Batista, 2005, p. 1). Diferente disso, "a linguagem pode ser despedaçada em coisas-palavras simplesmente dadas" (Heidegger, 2015, p. 224). Portanto, a obra de arte, com especial relevo na po- esia, é manancial de onde brotam a desocultação e a revelação de mundo e terra, nos termos heideggerianos. "A terra heideggeriana é o que os gregos chamavam de physis, ela é a natureza, onde o homem instalou-se e instalou seu mundo. A terra é mistério, o mundo tenta lhe dar lógica e é aí que ocorre o seu velamento" (Barros, 2005, p. 9).

No que pertine à poesia, "o poeta oferece um arranjo de palavras que constitui uma mensagem nova, jamais encontrada antes pelo leitor, porém logo reconhecida como expressão de uma vivência que poderia ser dele mesmo" (Augras, 2012, p.104). Nos termos acima aludidos, a poesia propicia o retorno à terra natal, um movimento que toca as disposições afetivas do Ser, que estivera esquecido ante a lógica metafísica que tentou explicá-lo, em linguagem técnica e parametrizada; ao revés, "a linguagem no poema é o poetizar de si mesmo" (Barros, 2005, p.13). Assim, a poesia é mensagem de possibilidades, distinta da linguagem ordinária, aquela se transmuta em diálogo; poesia é celebração e comemoração, ela revela o pathos do infortúnio, bem assim a renovação da esperança, através da palavra. (Nunes, 1992).

Resta cristalino, a partir das postulações de Heidegger (2003), que seu intento na interpretação de poesias vai de encontro a uma perspectiva de uma interpretação linguística que avalia a linguagem como signo. Igualmente, nessa direção, em Cartas sobre o Humanismo, Heidegger (2005) assevera que se julga o pensar a partir de uma medida julgada adequada; a linguagem, livre de uma Gramática hermética, encontra lugar original na poesia.

Um olhar heideggeriano aos poemas sugere, portanto, o encontro de um sentido no labirinto das palavras, uma busca ao impronunciado e à comunicação de possibilidades. Nesse contexto, a análise "volta-se para o poema como experiência privilegiada, que pode nos dar o falado em estado puro [...] (exercita) um ouvir o que não está expresso e sim latente na enunciação" (Nunes, 1992, p. 276).

Atentos a essa forma de iluminar a terra que surge em meio aos ruídos do mundo calculante é que intentaremos um mergulho à obra de Augusto dos Anjos, o poeta do hediondo, que, fugindo dos cânones estéticos e em rota de colisão com o que estava posto (embora em xeque) pela modernidade, poetiza para desnudar o Ser, descerrando o véu metafísico que o encobre e escavando suas disposições afetivas, por uma poética que subverte o instituído, dando relevo ao modo propriamente humano de estar no mundo (Santos, 2009).

\section{Em torno da poética de um "operário das ruínas".}

Faz-se importante, antes da viagem à sua obra, uma visada histórica à trajetória de Augusto dos Anjos, nascido em 20 de abril de 1884, no Engenho Pau 
d’arco, hoje Município de Sapé, na Paraíba. Um ser que "cismava, sofria, escrevia poemas, um homem magro e taciturno, que se tornaria conhecido na história da literatura brasileira" (Gullar, 1978, p. 15). O contexto histórico dos primeiros raios de sua existência, ele filho de proprietários de engenhos e sob o regime rural patriarcal, é de crise da classe latifundiária, suscitada pelas transformações econômicas, abolição da escravatura, uma nova face do capitalismo que, sob outro lema de progresso, concorre ao desmoronamento daquela estrutura agrária. Essa realidade determina a hipoteca das terras da família, em 1892. Seu pai morre me 1905, após longo período de inatividade, decorrente de doença cerebral. Em 1908, morre seu tio e dois anos após sua família vende o Engenho Pau d'arco. Augusto estudou no Liceu Paraibano, em 1903 ingressou no Curso de Direito da Faculdade de Recife, concluindo a graduação em 1907. Faleceu em 12 de novembro de 1914, aos 30 anos, em Leopoldina, Minas Gerais, onde exercia a função de Diretor de um estabelecimento escolar.

A afinação existencial que circunda a vida de Augusto dos Anjos é de decadência, dor, solidão e luto. Uma realidade pontilhada pela falência das famílias abastadas, degeneração social, que atestava o niilismo, a "vontade cega" do mundo e o pessimismo, presentes na leitura de Spencer, Heckel e Schopenhauer, pensadores que, segundo os críticos, marcaram sua visão de mundo. Esse é o cenário através do qual ele "indaga e sofre o mistério da existência. Jamais antes dele, na poesia brasileira, essa indagação se fizera em tal nível de urgência existencial e de expressão poética” (Gullar, 1978, p. 18). Esse ineditismo dificulta, para a crítica literária, uma precisa classificação literária da poesia anjosiana. Os movimentos parnasiano e simbolista, no momento em que Augusto expunha sua expressão poética, representavam as tendências hegemônicas na literatura brasileira, sendo indicados como influenciadores de sua formação. É cediço, no entanto, que ele não se filiou a nenhum deles, porque sua poética traz viva as questões humanas, para além da estética e da técnica. Antes de Augusto "quase sempre o poeta ocultou o homem. Talvez por isso mesmo [...] é que na obra do poeta paraibano, o homem aparece de maneira tão escandalosa, a exibir seus intestinos, seu cuspo, sua lepra, seu sexo, sua miséria” (Gullar, 1978, p.25). Na esteira das tentativas de enquadre da sua obra, Santos (2009) assevera e o reconhece como um poeta moderno, que esquadrinha a condição humana com um discurso contundente. Mesmo entendimento esposado por Gullar (1978), percebendo na obra do poeta paraibano, "não de maneira eventual, e sim como elemento constitutivo de sua linguagem, alguns traços que caracterizam a nova poesia, a que se convencionou chamar de poesia moderna” (Gullar, 1978, p. 29).

$\mathrm{O}$ impronunciado ou gritado na poesia de $\mathrm{Au}$ gusto é o teor humano, fenomenal de suas linhas; é linguagem que fala e traz à tona a existência e o ser, lançado no mundo, sobre o qual pesa a possibilidade de não ser (ser-para-morte) e que por isso se angustia ante o vivido em disposições afetivas e mecanismos de preservação, que o poeta do hediondo faz assomar ao universo poético sem o verniz que lhe emprestaram a estética e a metafísica. Em Augusto dos Anjos, a toda evidência, "a poesia é um compromisso total com a existência” (Gullar, 1978, p.36). Nesse sentido, uma poesia permeada por aspectos, que "representam as diversas dimensões de abertura do ser-aí à revelação do ser, no horizonte do tempo" (Zuben, 2011, p.89). Uma poesia que prima “por não se desprender do vivido, de não traí-lo, de não disfarçá-lo com delicadezas, de erguê-lo de sua vulgaridade à condição de poesia” (Gullar, 1978, p. 24).

É possível divisar o teor iconoclasta da poesia de Augusto dos Anjos, sua vocação ao desvelamento das relações e sua linguagem que fala dos calabouços humanos para, de lá, escutar o eco da angústia da existência e o frisson das possiblidades que se dão ao Ser, pela abertura originária ao mundo. Ele abre mão do domínio das palavras como representantes da estabilidade para, sob o signo da liberdade, dar visibilidade ao "inóspito, ao inseguro, que colocam o Dasein diante de si mesmo como ser-no-mundo, e para o qual apontou o fenômeno da angústia” (Nunes, 1992, p. 267). É nos termos de Heidegger (2003) a consolidação do entendimento que a "poesia de um poeta está sempre impronunciada” (p.28) e que do "lugar da poesia emerge uma onda que cada vez mais movimenta o dizer como uma saga poética [...] (e que) permite que toda movimentação do dizer seja reconduzida para a origem sempre mais velada" (p. 28). Um jogo de velamento - desvelamento, muito genuíno à poética de Augusto, perceptível, por exemplo, no poema $\mathrm{O}$ corrupião, abaixo transcrito:

\section{O corrupião}

Escaveirado corrupião idiota,

Olha a atmosfera livre, o amplo éter belo, E a alga criptógama e a úsnea e o cogumelo, Que do fundo do chão todo o ano brota!

Mas a ânsia de alto voar, de à antiga rota Voar, não tens mais! E pois, preto e amarelo, Pões-te a assobiar, bruto, sem cerebelo A gargalhada da última derrota!

A gaiola aboliu tua vontade.

Tu nunca mais verás a liberdade! ...

Ah! Tu somente ainda és igual a mim.

Continua a comer teu milho alpiste.

Foi este mundo que me fez tão triste, Foi a gaiola que te pôs assim!

(Anjos, 1998, p. 112) 
Na poesia de Augusto dos Anjos, a angústia estampada no ser que olha para o entorno sob uma "estranha tranquilidade", ante um mundo que lhe fez, indeterminadamente, tão triste e lhe revela o nada. Linhas que sugerem a facticidade da existência, esta sempre propensa e vulnerável à angústia originária, que, nos termos heideggerianos, pode assomar a qualquer momento, no ser-aí, posto que "está continuamente à espreita e, contudo, apenas raramente salta sobre nós para arrastar-nos à situação em que nos sentimos suspensos" (Heidegger, 2008, p. 128).

Importa afirmar, também, que a poesia de $\mathrm{Au}$ gusto dos Anjos sugere um deslocamento do impessoal diante da morte. Esse impessoal arregimenta uma indiferença superior ante o fim, que "aliena a presença de seu poder-ser mais próprio e irremissível” (Heidegger, 2015, p.330). Ao fazê-lo, todavia, põe-se em marcha um modo de ser da decadência. "Decadente o ser-para-a-morte cotidiano é uma insistente fuga dele mesmo. O ser-para-o-fim possui um modo de escape dele mesmo, que desvirtua, vela e compreende impropriamente" (Heidegger, 2015, p. 330). No poema Último credo, abaixo transcrito, é patente a compreensão da finitude e um movimento desencobridor da morte e a assunção pessoal do fenômeno:

\section{Último credo}

Como ama o homem adúltero o adultério

E o ébrio a garrafa tóxica do rum,

Amo o coveiro - este ladrão comum

Que arrasta gente para o cemitério

É o transcendentalíssimo mistério!

É o nous, é o pneuma, é o ego sum qui sum

É a morte, é esse danado número Um

Que matou Cristo e que matou Tibério!

Creio, como o filósofo mais crente,

Na generalidade decrescente

Com que a substância cósmica evolui

Creio perante a evolução imensa,

O homem universal de amanhã vença

O homem particular eu que ontem fui!

(Anjos, 1998, p. 77)

Observa-se um percurso diverso do que ocorre na medianidade, quando "esse fato fica velado porque transforma-se a morte num caso da morte dos outros, que ocorre todos os dias e que, de todo modo, nos assegura com mais evidência que 'ainda se está vivo"” (Heidegger, 1927/2015, p. 330).

Para Heidegger "todo grande poeta só é poeta de uma única poesia" (Heidegger, 2003, p.27). Sendo essa poesia um selo do poeta, figurando sempre impronunciada, cujo lugar pode ser desvelado a partir do olhar que se lança a cada poema isolado.
A admissão de que "cada poema necessita assim de um esclarecimento. O esclarecimento deixa brilhar como numa primeira vez o clarim da claridade que transluz no que se diz poeticamente" (Heidegger, 2003, p. 28).

Nossa ingente tarefa é o estabelecimento de um diálogo com a poesia de Augusto, pelas alamedas e vielas de seus poemas, pelas quais a linguagem passeia e nos convida à sua casa. É pensar com Heidegger que "o diálogo propriamente dito com a poesia de um poeta só pode ser um diálogo poético: a conversa poética entre poetas" (Heidegger, 2003, p.28).

\section{Pelo assombro da existência: a caminho de Augusto.}

Somente a Arte, esculpindo a humana mágoa, Abranda as rochas rígidas, torna água

Todo o fogo telúrico profundo E reduz, sem que, no entanto, a desintegre, À condição de uma planície alegre, A aspereza orográfica do mundo (Anjos, 1998, p.53)

Refletindo os caminhos possíveis ao estabelecimento do diálogo a que o título deste ensaio alude, o trecho do poema Monólogo de uma sombra, acima transcrito, sugere a convergência. Em verdade, esse fundamento é central à poesia, haja vista que ela, suspendendo a comunicação regular "é diferenciação da linguagem ordinária, fazendo-a passar de estado público, da perspectiva do ser-em-comum, ao diálogo" (Nunes, 1992, p. 275). Por sua vez, o vocábulo caminho articula várias obras de Heidegger (Caminhos de floresta, Marcas do caminho, O caminho do campo, A caminho da linguagem, Meu caminho para a fenomenologia) e figura como epígrafe para a edição de sua Gesamtausgabe (obra completa), sugerindo possibilidades, aberturas ao mundo. Dentre elas a arte, uma possibilidade atravessada pela liberdade e reveladora do ser, que é aí, que é para-si e é para-o-outro em disposições de monólogos e diálogos. Linguagem que ilumina o mundo e a existência, apontando por contrates e trazendo à clareira (planície) do ser elementos engolfados pela técnica, parametrizados pelos ditames da ciência e o envoltório da estética; como é igualmente possível perceber em trecho do mesmo poema, abaixo grafado:

Provo desta maneira ao mundo odiento Pelas grandes razões do sentimento Sem os métodos da abstrusa ciência fria E os trovões gritadores da dialética, Que a mais alta expressão da dor estética Consiste essencialmente na alegria

(Anjos, 1998, p.53) 
Transitar pelos caminhos da poesia de Augusto, reiteramos, é visitar as veredas da angústia que, como disposição afetiva fundamental, suscita a abertura ao mundo sem sugerir de onde provém o tom ameaçador. "Na angústia, não se dá o encontro disso ou daquilo com o qual se pudesse estabelecer uma conjuntura ameaçadora" (Heidegger, 1927/2015, p. 253). Em trecho do poema "Os doentes" é possível identificar essa afinação, um encontro com o inominado, com o que não se sabe como ou porque o angustia:

Minha angústia feroz não tinha nome.

Ali, na urbe natal do Desconsolo, Eu tinha que comer o último bolo Que Deus fazia para minha fome! (Anjos, 1998, p.80)

Possível também esse vislumbre no poema "Eterna Mágoa":

\section{Eterna Mágoa}

O homem por sobre quem caiu a praga Da tristeza do Mundo, o homem que é triste Para todos os séculos existe E nunca mais o seu pesar se apaga

Não crê em nada, pois, nada há que traga Consolo à Mágoa, a que só ele assiste. Quer resistir, e quanto mais resiste Mais se lhe aumenta e se lhe afunda a chaga.

Sabe que sofre, mas o que não sabe É que essa mágoa infinda assim, não cabe Na sua vida, é que essa mágoa infinda

Transpõe a vida do seu corpo inerme;

E quando esse homem se transforma em verme É essa mágoa que o acompanha ainda!

(Anjos, 1998, p.126)

Em causa, como depreendemos na poética de Augusto, o escancaramento do cotidiano, realçando a morte como fenômeno material e real, situado na cotidianidade para a qual olha de frente, retirando-lhe o véu da inautenticidade e mostrando as vísceras da condição humana - permeada de afetações. Percepção cristalina no poema "A meu pai morto":

\section{A meu pai morto}

Madrugada de Treze de Janeiro,

Rezo, sonhando, o ofício da agonia.

Meu Pai nessa hora junto a mim morria

Sem um gemido, assim como um cordeiro!

E eu nem lhe ouvi o alento derradeiro!

Quando acordei, cuidei que ele dormia, E disse à minha Mãe que me dizia:
"Acorda-o"! deixa-o, Mãe, dormir primeiro!

E saí para ver a Natureza!

Em tudo o mesmo abismo de beleza,

Nem uma névoa no estrelado véu...

Mas pareceu-me, entre as estrelas flóreas,

Como Elias, num carro azul de glórias,

Ver a alma de meu Pai subindo ao Céu!

(Anjos, 1998, p.109/110)

Estabelecidos os fronteiriços territórios do poeta e do pensador, faz-se mister entender o diálogo a que o presente estudo se propõe tecer, considerando que a Hermenêutica heideggeriana da passagem para o poético sugere que "os poetas e pensadores, próximos entre si na medida em que atendem ao mesmo apelo do ser na linguagem, estariam a grande distância uns dos outros por força do dizer que os avizinha” (Nunes, 1992, p.280). Para Heidegger, o pensamento fala o ser, enquanto o poeta nomina o sagrado. Assim é que, na obra A caminho da linguagem, em que pensa poemas de Georg Trakl, Heidegger exara o seguinte entendimento:

Fazer uma colocação a partir da poesia não pode substituir e muito menos orientar a escuta dos poemas. A colocação de pensamento pode, no máximo, elevar a escuta à dignidade de uma questão e, no melhor dos casos, a algo para se pensar ainda mais o sentido (Heidegger, 2003, p.29)

Tendo presente esse cuidado, do não direcionamento e nem de sujeição da poesia aos grilhões de uma análise literária, intentamos pensar quatro estrofes do poema "Versos de Amor", da lavra de Augusto dos Anjos:

\section{Versos de amor}

Parece muito doce aquela cana.

Descasco-a, provo-a, chupo-a, ilusão treda.

O amor, poeta, é como a cana azeda,

A toda boca que não prova engana.

Quis saber o que era amor, por experiência E hoje que, enfim, conheço seu conteúdo, Pudera eu ter, eu que idolatro o estudo, Todas as ciências, menos esta ciência!

[..]

Para reproduzir tal sentimento

Daqui por diante, atenta a orelha cauta,

Como Mársias - o inventor da flauta -

Vou inventar também outro instrumento

Mas de tal arte e espécie tal fazê-lo Ambiciono, que o idioma em que te falo Possam todas as línguas decliná-lo Possam todos os homens compreendê-lo! (Anjos, 1998, p.107/108) 
O poema em tela argui questão importante da existência; mergulhados no mundo, os Seres tecem teias relacionais, cujas significações, em regra encobertas por expectativas sociais e glamourizadas por um conjunto de normas, resistem a um conhecimento técnico e a preceitos sociais que as perseguem para decifrar-lhes.

$\mathrm{Na}$ primeira estrofe, o poeta apresenta o amor, relacionando-o ao sabor da cana (pressupostamente doce), que remete aos mais íntimos desejos de prazer. ("parece muito doce aquela cana"). Não obstante esse enlevo, um véu é descerrado para trazer à tona outra possibilidade. Em realidade, nem sempre a cana é doce, nem todo amor é serenidade; mesmo e, sobretudo, os grandes amores padecem dos enganos, das incertezas, das angústias que têm de sustentar na cotidianidade. Logo, "o amor poeta é como a cana azeda, a toda boca que não prova engana”.

Na segunda estrofe, uma referência à experiência. O poeta insinua que mergulhou no amor, para além das expectativas sociais e do falatório que lhe glamouriza. Em face do outro e do cuidado com o outro, provou do amor na perspectiva da experiência, tendo assim compreendido seu conteúdo. E a experiência suscita a angústia, expressa em "Pudera eu ter, eu que idolatro o estudo, todas as ciências menos esta ciência”. Remeter a experiência do amor ao enquadre da ciência é afirmar que, no jogo do mundo, um sentimento profundo, fenomenal vê-se preso aos cânones e quadraturas de um enredo social, que lhe tolhe os movimentos, que molda seu caminhar e subtrai-lhe a liberdade.

A terceira estrofe destacada, tendo viva a experiência do amor-realidade, sugere que, armando-se de um outro modo de olhar a questão, o amante não desiste da empreitada de amar. Ele quer "reproduzir tal sentimento", mas muda a perspectiva de imiscuir-se na relação e na compreensão desse sentimento. Para tanto, "atenta a orelha cauta" (escutando com agudeza e prudência, distinguindo os murmúrios mundanos) ele vai igual a Mársias "inventar outro instrumento". Um novo modo para acessar o sentimento de estar com o outro, distinto (o modo) das medidas que lhe emprestaram as bulas sociais e as palavras dadas.

Por fim, na quarta estrofe, há um rompimento com a linguagem ordinária. O poeta não desiste do sentimento, mas quer acessá-lo e transmiti-lo ao ser amado por outro idioma. Mas esse idioma é de uma natureza não convencional, não acessível a todas as línguas, que dele têm declinado. $\mathrm{O}$ arremate do poema é a ideia da compreensão, que antecede todas as línguas e se subleva a todos os conceitos - um idioma, em que pese o fato de que "Possam todas as línguas, decliná-lo"; na intensidade e singularidade do estar no mundo com o outro, que a ciência não alcança, "Possam todos os homens compreendê-lo", numa linguagem que resgata o Ser-que-ama.

\section{Considerações finais}

Interessou-nos, ao longo desse estudo, além do necessário e sempre renovado retorno ao universo da fenomenologia existencial, caminhar pelas trilhas do pensamento de Heidegger, especialmente em seu momento de viragem poética. Da Floresta Negra rumamos às clareiras virginais da existência para, através da fala da linguagem, remontar o resgate do Ser e seu sentido, do qual Heidegger sempre esteve a caminho de desvelar, de fazer falar, com liberdade, falando e sendo - com o mundo e com o outro. A arte poética foi o guia a sugerir-nos as várias possiblidades de clarificar a morada do Ser, na qual pensadores e poetas (seus guardiões) desocultam suas manifestações - os primeiros dizendo dele e os poetas restituindo-lhe o sagrado, em relação dialógica.

Nesse compasso, dos pinheiros e abetos daquela floresta, sentamos à sombra do Tamarindo de Augusto dos Anjos, entrelaçando seus galhos num diálogo profícuo entre pensamento e poesia. Augusto, um ser inquieto que vaga entre a infância no Engenho Pau D'arco, em decrepitude, e a juventude em Recife da Ponte Buarque de Macedo em que ele "Assombrado com a minha sombra magra, pensava no destino e tinha medo" (Anjos, 1998, p.60). Augusto, o escolhido paraibano do século XX, o poeta lido pela crítica como poeta do hediondo, do infortúnio, o "operário das ruínas". Estes epítetos lhe foram dirigidos por ele resgatar, em suas linhas, o mundo em estado puro e uma linguagem como possibilidade de sentido e descerramento dos "véus" que nublam a terra e projetam o mundo. Relacionada ao pessimismo, ao horror e ao mau gosto, a poesia de Augusto tem o condão de desnudar a realidade. A repulsa a seus poemas "quem sabe não é também um resquício das concepções estéticas, hoje superadas, que viam a arte como a expressão do belo e dela excluíam a matéria mesma da vida?" (Gullar, 1978, p.58).

Foi essa "matéria da vida" que Heidegger, às escâncaras, trouxe à tona em sua opção pelo Ser, que se revela na facticidade, diante da angústia colada à existência e da possibilidade extrema do não-ser, em face de sua inarredável condição de ser-para-a-morte. Seu pensamento desalojou a técnica como panaceia moderna, sugerindo movimentos que trouxessem ao homem uma existência mais reveladora de si mesmo. Em certo momento, esse pensar se volta à Arte e à arte de dialogar pensamento com a poesia; é nessa tarefa que "a Hermenêutica heideggeriana consigna a conversão, que se operou ao longo da História do ser, de poiésis em expressividade criadora, de logos em Lógica, da phýsis em princípio da Natureza, da tchené em simples fazer artístico, e da mímesis em imitação de modelos” (Nunes, 1992, p.281), redescobrindo o sagrado e o lógos como manifestações do Ser e situando a poesia como sua topologia.

Gritados ou impronunciados, esses elementos estão presentes na poética de Augusto dos Anjos, 
que labora para arrancar o Ser da aparência. Aspectos que, mesmo cientes do caráter exploratório (mas instigante) do estudo, tentou-se realçar, em olhares que lançamos a alguns de seus poemas, articulando o diálogo que o texto enseja, mesmo considerando a distância entre os Pinheiros da Floresta Negra da Alemanha e o Tamarindo do Nordeste brasileiro; vez que, embora distantes, vislumbramos o que os une: o húmus da gênese do homem, seu grito de liberdade e "frialdade inorgânica da terra" - presentes no Ser e que se revelam pelas janelas de sua morada.

\section{Referências}

Anjos, A. (1998). Eu e Outras Poesias. $42^{\mathrm{a}}$ Ed. Rio de Janeiro: Civilização Brasileira.

Augras, M. (2012). O ser da Compreensão: fenomenologia da situação do psicodiagnóstico. Petrópolis: Vozes.

Barros, C. M. S. (2005). A poesia na Filosofia Heideggereana: uma breve investigação rumo à crítica. Terra roxa e outras terras - Revista de Estudos Literários, 5. ISSN 1678-2054, 2-16

Batista, J. B. (2005). A verdade do Ser como Alethéia e Errância. Existência e Arte, 1(1), 1-5.

Bauman, Z. (2005). Vidas Desperdiçadas. Rio de Janeiro: Jorge Zahar.

Dartigues, A. (2005). O que é fenomenologia? São Paulo: Centauro.

Dilthey, W. (2011). Ideias sobre uma psicologia descritiva e analítica. Rio de Janeiro: Via Verita.

Giles, T. R. (1989). História do Existencialismo e da Fenomenologia. São Paulo: EPU

Goto, T. A. (2008). Introdução à Psicologia Fenomenológica: A nova psicologia de Edmund Husserl. São Paulo: Paulus.

Gullar, F. (1978). Augusto dos Anjos. Toda Poesia; com um estudo crítico de Ferreira Gullar: Augusto dos Anjos ou Vida e Morte Nordestina. Rio de Janeiro: Paz e Terra.

Heidegger, M. (2003). A caminho da linguagem. Petrópolis: RJ: Vozes; Bragança Paulista: SP: Editora Universitária São Francisco.

Heidegger, M. (2005). Carta sobre o humanismo. São Paulo: Centauro.

Heidegger, M. (2008). Marcas do Caminho. Petrópolis, RJ: Vozes.

Heidegger, M. (2015). Ser e Tempo. Tradução de Márcia Sá Cavalcante Schuback Petrópolis, RJ: Vozes; Bragança Paulista, SP: Editora Universitária São Francisco. (Edição original de 1927).
Holanda, A. F (2014). Fenomenologia e Humanismo: reflexões necessárias. Curitiba: Juruá.

Nunes, B. (1992). Passagem para o poético (Filosofia e poesia em Heidegger). São Paulo: Editora Ática.

Roehe, M. V (2006). Uma abordagem fenomenológico-existencial para a questão do conhecimento em psicologia. Estudos de Psicologia, 11 (2), 153-158.

Sá, R. N. (2013). As influências da fenomenologia e do existencialismo na psicologia. Em A. M. Jacó-Vilela; A. A. L. Ferreira, \& F. T. Portugal, (Orgs.). História da Psicologia: rumos e percursos. (pp. 361-380). Rio de Janeiro: Nau Editora.

Santos, I. M. C. M. (2009) O Arbusto dos Anjos. Dissertação de Mestrado. Centro de Ciências Humanas Letras e Artes. Departamento de Letras. Universidade Federal do Rio Grande do Norte.

Silva, J. C. (2012). Primeiras notas a O fim da filosofia e a tarefa do pensamento (Martin Heidegger) - exposição de premissas e pressuposições a problemas filosóficos em questão. Revista Estudos Filosóficos, 9, 151-165, ISSN 2177-2967.

Souza, L. R. A, Leal, I. F \& Sá, R. N. (2010). Atitude Fenomenológica e Psicoterapia. Revista IGT, 7 (37), 223-245.

Zuben, N. A. (2011) A Fenomenologia como Retorno à Ontologia em Martin Heidegger. Revista Trans/Form/Ação, 34(2), 85-102

Francisco Bento da Silva Filho (Orcid: 0000-00028325-4238) tem Graduação em Psicologia, Pedagogia e em Ciências Contábeis pela Universidade Federal da Paraíba, Especialista em Sexualidade Humana e Mestrado em Educação pela Universidade Federal da Paraíba, Especialista em Psicologia Clínica Fenomenológica pela UFRN. Atualmente é professor das Faculdades Integradas de Patos. Pesquisador do Grupo de Pesquisa em Psicologia Fenomenológica Existencial do Departamento de Psicologia da UFPB e Professor do Sistema Pronatec/IFPB. Endereço Institucional: Faculdades Integradas de Patos. Rua Manoel Gualberto Miramar. 58043150 - João Pessoa, PB - Brasil. Email: otnebbpsi@gmail.com

Symone Fernandes de Melo (Orcid: 0000-0003-38999916) possui mestrado em Psicologia Clínica pela Universidade de São Paulo (2000) e doutorado em Psicologia (Psicologia Cognitiva) pela Universidade Federal de Pernambuco (2006). Atualmente é Professor Associado da Universidade Federal do Rio Grande do Norte. Email: symelo@gmail.com

Recebido em 23.09.2017 Primeira Decisão Editorial em 20.04.2018 Aceito em 20.02.2019 